\title{
ANALISIS PERANCANGAN APLIKASI SISTEM INFORMASI E-MCARD BERBASIS ANDROID PADA PT. XYZ
}

\author{
Meritha Indah Sari ${ }^{1}$, Danny Yudin Djahidin ${ }^{2}$ \\ Fakultas Ilmu Komputer, Universitas Mercu Buana ${ }^{1,2}$ \\ merithaindah185@gmail.com ${ }^{1}$, danny.yudin@ mercubuana.ac.id ${ }^{2}$
}

\begin{abstract}
Abstrak: PT. XYZ merupakan sebuah perusahaan Farmasi lokal Indonesia yang sedang berkembang pada saat ini, dimana pada perkembangan suatu perusahaan peranan Teknologi Informasi sangatlah penting seiring dengan perkembangan jaman yang sangat pesat. PT. XYZdalam penerapan Teknologi Informasi pengolahan data sudah cukup baik dan memiliki sistem informasi yang dapat memudahkan pekerjanya untuk menganalisa data. Namun masih memiliki kendala didalam proses pembuatan laporan data kunjungan Karyawan Bagian Pemasaran yang berpengaruh terhadap gaji dan insentif Karyawan Bagian Pemasarantersebut.Tujuan dari penelitian ini adalah untuk dapat mengukur proses pencapaian target call yang diberikan Perusahaan kepada masing-masing Karyawan Bagian Pemasaran, mempermudah promosi produk kepada dokter, dan membantu memonitoring aktifitas target penjualan, dimana peneliti menggunakan Metode Analisis SWOT dan Fishbone dalam proses Analisis dan perancangan Sistem Informasi tersebut
\end{abstract}

Abstract: PT. XYZ is a local Indonesian pharmaceutical company that is currently developing, where in the development of a company the role of Information Technology is very important along with the very rapid development.PT. XYZ in the application of Information Technology data processing is quite good and has an information system that can be used to analyze data. But there are still problems in the process of making a report about a Marketing employees visit that affects the salaries and incentives of the Marketing department.The purpose of this study is to be able to measure the process of achieving the target of visits given by the Company to each of the Marketing Department Employees,product promotion to doctors, and help monitor sales targets, where researchers use the SWOT and Fishbone Analysis Methods in the analysis process.

\section{Keywords: Analisis, Perancangan, Android, SWOT, Fishbone}

\section{PENDAHULUAN}

Penggunaan Teknologi dan Informasi di dalam suatu perusahaan mampu menciptakan keunggulan yang kompetitif dan menjadi sasaran utama dari upaya penerapan IS/IT di perusahaan. [1]

Dimana saat ini perkembangan organisasi yang semakin komplek mengakibatkan kebutuhan akan informasi dan data akan semakin meningkat. Untuk memenuhi kebutuhan tersebut maka diperlukan sebuah sistem informasi yang dapat mendukung proses bisnis yang berjalan di organisasi yang menyediakan data atau informasi berkualitas yang bertujuan untuk mengurangi biaya, meningkatkan produktifitas, menyediakan fasilitas berbagi data dan informasi serta meningkatkan pelayanan terhadap customer. [2]

PT. XYZ dalam penerapan Teknologi Informasi pengolahan data sudah cukup baik dan memiliki sistem informasi yang dapat memudahkan pekerjanya untuk menganalisa data. Namun masih memiliki kendala didalam proses pembuatan laporan data kunjungan karyawan bagian pemasaran yang berpengaruh terhadap gaji dan insentif karyawan tesebut tersebut, dimana saat ini PT. XYZ masih melakukan tanda tangan manual pada Form Kartu Kunjungan disetiap Rumah Sakit dan Apotik yang telah di kunjungi. Hal ini berpengaruh juga terhadap biaya yang dikeluarkan setiap bulannya untuk mencetak Kartu Kunjungan. Setiap karyawan pemasaran memiliki wajib kunjungan 40 User untuk Level Staf, dan 25 User untuk level Supervisor di setiap bulannya.

Dalam hal ini, karyawan bagian pemasaran juga sering menghadapi beberapa kendala yakni, Kartu kunjungan sering tertinggal, basah akibat terkena air, kolom paraf yang terlalu kecil dan sering terjadi kehilangan. Kendala tersebut sangat berpengaruh terhadap kinerja yang tidak dapat 
maksimal pada karyawan itu sendiri. Maka suatu Aplikasi Sistem Informasi Berbasis Android untuk membantu kelancaran Karyawan bagian pemasaran dalam proses bisnis tersebut.Dimana Metode analisis yang akan digunakan dalam menganalisis masalah yakni Metode Analisi SWOT dan Fishbone. adalah:

Tujuan dari analisis dan perancangan ini

1. Mengukur seberapa besar pencapaian atas target kunjungan yang diberikan PT XYZ kepada masing-masing karyawan bagian pemasaran.

2. Memberikan kemudahan kepada karyawan bagian pemasaran untuk dapat memperkenalkan, mempromosikan dan menjelaskan produk dengan baik kepada user.

3. Membantu memonitoring aktivitas target penjualan pada masing-masing karyawan bagian pemasaran, sehingga karyawan tersebut dapat dengan mudah melihat kekurangan target penjualan.

4. Membantu mengetahui aktivitas pemberian support event workshop dan symposium user, agar karyawan bagian pemasaran dapat lebih efektif dalam memberikan support event tersebut

5. Membantu memonitoring aktivitas pemberian PROMAT kepada user

\section{TINJAUAN PUSTAKA}

Berikut adalah beberapa tinjauan pustaka terkait analisis dan perancangan menggunakan metode analisis SWOT dan Fishbone dan seberapa beasar peran Teknologi Informasi dalam proses bisnis :

1. Penelitian yang dilakukan oleh Andrew Kurniawan Vadreas dalam penelitiannya yang berjudul "Aplikasi E-Commerce dengan metode fishbone analisis pada usaha dagang hasil laut di sikakap kabupaten kepulauan mentawai menuju masyarakat ekonomi ASEAN ( MEA )" Dalam analisis ini permasalahan yang dihadapi yaitu : rendahnya produktivitas, dimana keadaan tersebut disebabkan oleh masalah internal yang dihadapi yakni : rendahnya kualitas SDM dalam manajemen,organisasi, penguasaan teknologi dan pasar. Penulis mengimplementasi metode Fishbone dalam analisis permasalahan, dimana hasil dari analisis tersebut berupa terciptanya model sistem E-commerce yang terintegrasi antara usaha dagang hasil laut sebagai penjual dan pembeli berbasis teknologi informasi dimana hasil daripenelitian ini sesuai dengan rencana kegiatan baik dalam aspek produksi maupun manajemen usaha.[3]

2. Penelitian yang dilakuakn oleh Trio Indra Ruhmana dan Erik Hadi Saputra dalam penelitiannya yang berjudul "Perancangan aplikasi untuk sirkulasi pakan ternak ayam broiler pada peternakan sumber jaya magelang"Dalam penelitian ini permasalahan atau kendala yang dihadapi oleh peternakan Sumber Jaya Magelang yakni Sistem informasi yang masih minim,laporan yang dihasilkan tidak tepat waktu dan agak lambat karena masih ada bagian yang dikerjakan secara manual. Metode yang digunakan dalam menganalisis masalah adalah Metode Analisis SWOT, dimana metode ini juga digunakan sebagai alat ukur untuk menentukan sebuah sistem dan menempatkan situasi dan kondisi sebagai faktor masukan yang kemudian dikelompokan menurut kontribusinya masing-masing. Penelitian ini menghasilkan perancangan aplikasi yang dapat membantu proses kerja pada Sumber Jaya Magelang yang diharapkan proses pengolahan data, pencarian data dan pembuatan laporan akan lebih mudah dan cepat sehingga dapat meningkatkan pelayanan yang ada. [4]

3. Penelitian yang dilakukan oleh Irnawati dalam penelitiannya yang berjudul "Peran Teknologi Informasi Dalam Meningkatkan sistem pemasaran" Penelitian ini merupakan penelitian pengujian hipotesis untuk mengetahui kaitan teknologi terhadap kinerja berbasis teknologi informasi serta menilai manfaat penggunaan 
teknologi informasi bagi perusahaan sehingga dapat dilihat bagaimana kinerja perusahaan tersebut. Adapun hasil dari penelitian ini yakni Teknologi informasi secara signifikan dan simultan berpengaruh terhadap kinerja karyawan bagian pemasaran dengan kontribusi sebesar 57\%. Artinya teknologi Informsi atau Sistem yang digunakan untuk pemasaran sangat berpengeruh terhadap kinerja perusahaan. [5]

\section{METODE PENELITIAN}

Metode Pengumpulan data dalam analisis dan perancanga E-MCard ini ada dua metode yang dilakukan yakni sebagai berikut :

1. Studi Literatur

Pada tahap ini, penulis mencari beberapa referensi buku dan literatur penelelitian terdahulu yang memiliki kesamaan dalam menganalisis masalah dan merancang sistem informasi berbasis Android.

2. Observasi

Penulis mengadakan penelitian dan peninjauan langsung terhadap permasalahan yang diambil, agar penyusun dapat mengetahui apa saja yang terdapat pada Analisis dan perancangan Sistem Informasi EMCard berbasisn Android.

Berikut adalah alur penelitian :

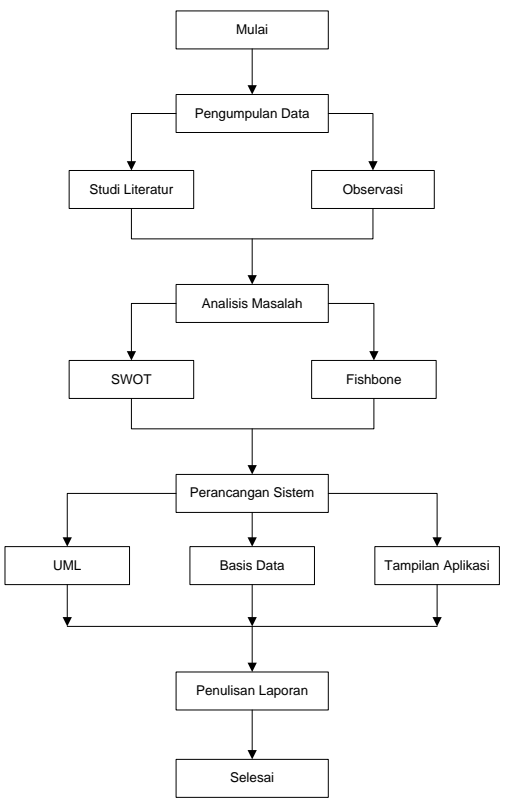

\section{METODE ANALISIS} Analisi SWOT

Analisis Swot adalah identifikasi berbagai factor secara sistematis untuk merumuskan strategi perusahaan. Analisis ini didasarkan pada logika yang dapat memaksimalkan kekuatan (Strengths) dan peluang (Opportunities), namun secara bersamaan dapat meminimalkan kelemahan (Weaknesses) dan ancaman (Threats). Proses pengambilan keputusan strategi selalu berkaitan dengan pengembangan misi, tujuan, strategis, dan kebijakan perusahaan. Dengan demikian, perencanaan strategis (strategic planner) harus menganalisis faktor-faktor strategis perusahaan (kekuatan, kelemahan, peluang, dan ancaman) dalam kondisi yang ada saat ini.[4]

Berikut adalah hasil analisis SWOT :

Strength ( Kekuatan )

- Memiliki produk Pangkreatin unggulan dimana hanya produk tersebut merupakan satu-satunya produk yang berlabel halal di Indonesia.

- Memiliki jaringan distribusi yang luas dimana PT. Metiska Farma bekerja sama dengan 5 Distributor ternama di Indonesia

- Memiliki Strategi pemasaran yang baik

- Memiliki 30 cabang yang tersebar di seluruh Indonesia.

Weakness ( Kelemahan )

- Karyawan bagian pemasaran masih menggunakan cara manual dalam melakukan kunjungan ke berbagai instansi Rumah Sakit / Klinik yakni meminta tanda tangan pada instansi yang telah dikunjungi maupun pembuatan laporan atas kunjungan tesebut dimana karyawan bagian pemasaran menghitung jumlah kunjungan yang telah dilakukan.

- Biaya yang cukup besar dikeluarkan untuk mencetak kartu kunjungan dan brosur yang di cetak 4 - 5 kali dalam 1 tahun.

- Stok brosur yang tidak menentu membuat karyawan bagian pemasaran terkendala dalam menawarkan dan menjelaskan produk yang ingin ditawarkan kepada user.

- Sering terjadi pemberian double support kepada user yang seharusnya support tersebut hanya dapat diberikan 1 kali saja dalam satu periode ( 6 bulan)

Gambar 1 Diagram Alur Penelitian 
Opportunity ( Peluang )

- Mendapatkan User baru disetiap bulannya

- Mendapatkan Instansi / Apotek baru untuk bekerjasama

- Memperkecil biaya pencetakan Brosur dan kartu kunjungan

- Mengembangkan reputasi perusahaan

Threats (Ancaman)

- Sebagian besar perusahaan farmasi sudah memiliki Aplikasi Elektronik Mobile dalam proses kerja Karyawan bagian pemasaran.

- Ketatnya persaingan dalam hal pemberian Support Event kepada User.

- Regulasi pemerintah terkait BPJS ( Badan Penyelenggara Jaminan Sosial ) dimana regulasi ini berdampak pada penjualan produk-produk bermerek

\section{Analisis Fishbone}

Analisis Fishbone Fishbone diagram (diagram tulang ikan) sering disebut juga diagram Ishikawa atau cause-and-effect diagram (diagram sebab-akibat)Fishbone diagram adalah alat untuk mengidentifikasi berbagai sebab potensial dari satu efek atau masalah, dan menganalisis masalah tersebut melalui sesi brainstorming. Fungsi dasarnya adalah untuk mengidentifikasi dan mengorganisasi penyebab-penyebab yang mungkin timbul dari suatu efek spesifik dan kemudian memisahkan akar penyebabnya. [6]

Berikut adalah hasil analisa fishbone:

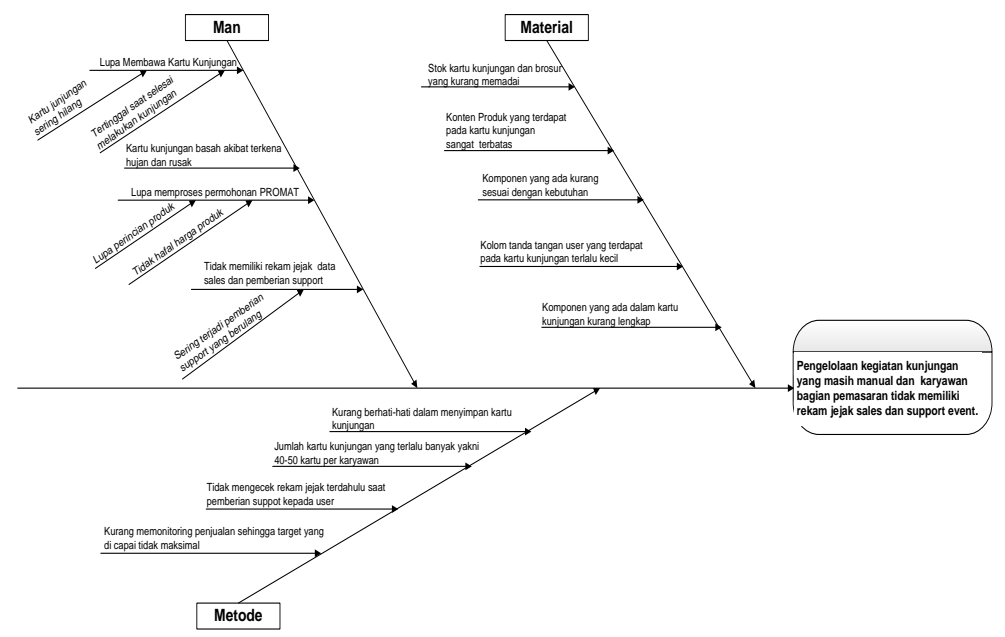

Gambar 2 Diagram Analisis Fishbone

\section{PERANCANGAN SISTEM \\ Use Case Diagram}

Use case merupakan fungsionalitas dari suatu sistem, sehingga user sebagai pengguna sistem paham dan mengerti mengenai kegunaan sistem yang akan dibangun.[6]

Berikut adalah use case E-MCard :

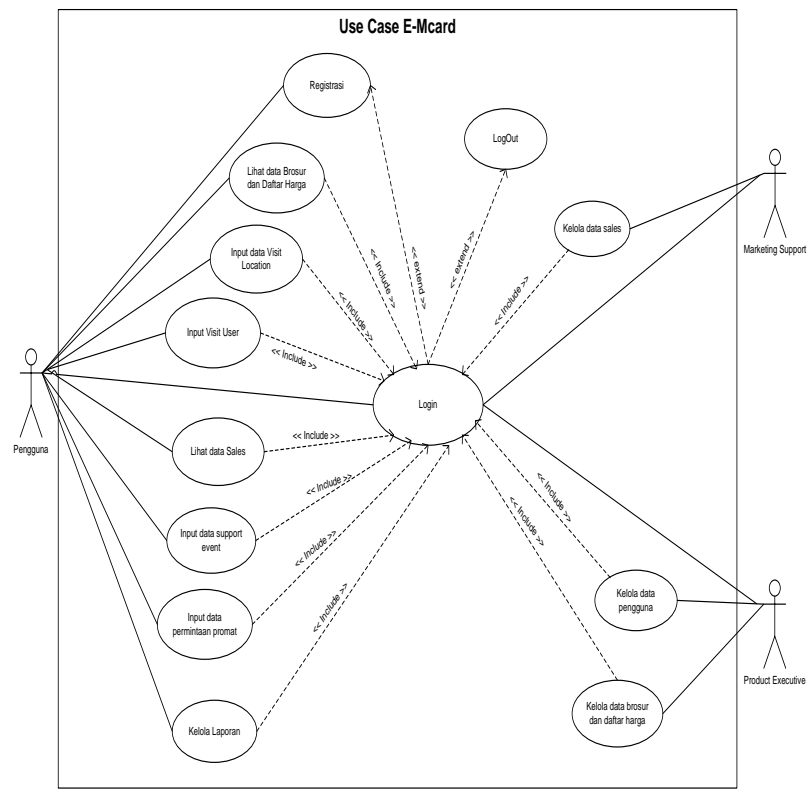

Gambar 3Use Case E-MCard

$\begin{array}{lr}\text { Fakultas Teknik UMSB } & \text { ISSN 2599-2081 } \\ & \text { EISSN 2599-2090 }\end{array}$


Diagram ini adalah tipe khusus dari diagram state yang memperlihatkan aliran dari suatu aktifitas ke aktifitas lainnya dari suatu sistem. Diagram ini terutama penting dalam pemodelan fungsi - fungsi dalam suatu sistem dan memberi tekanan pada aliran kendali antar objek.[7]

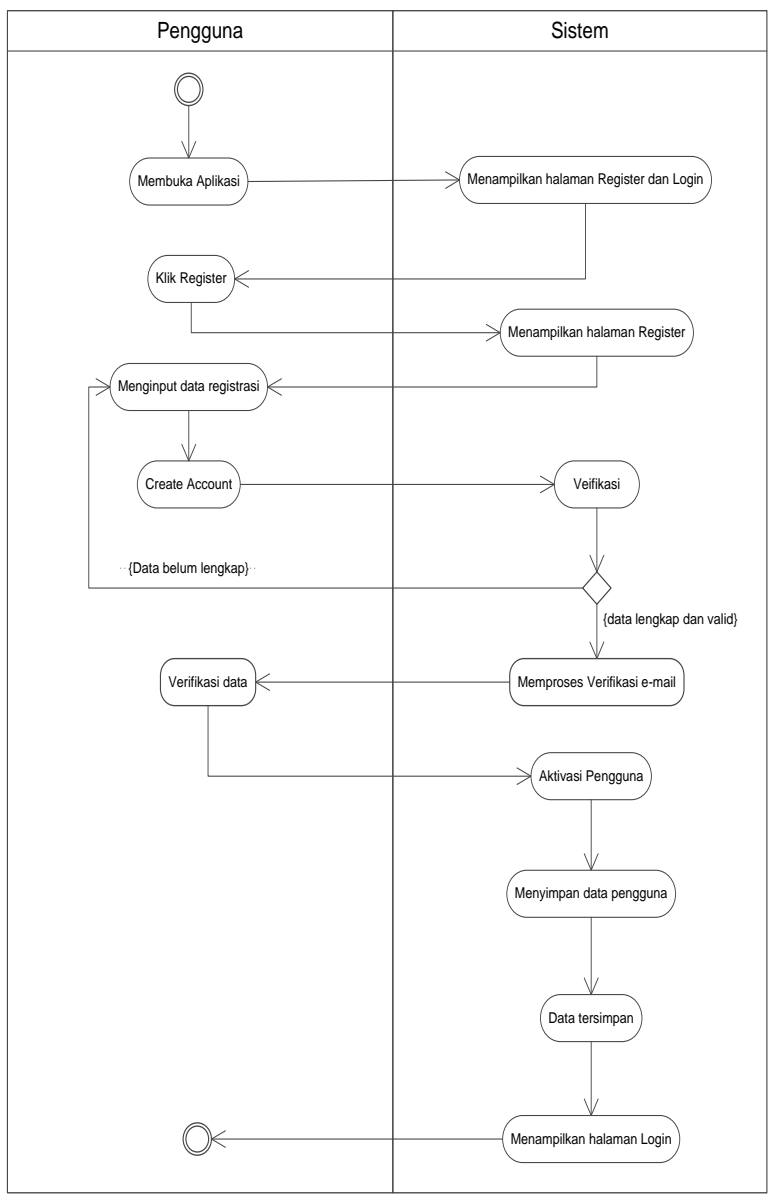

Gambar 4Activity Diagram

\section{Sequence Diagram}

Sequence Diagram menggambarkan kelakuan objek pada use casedengan mendeskripsikan waktu hidup objek dan message yang dikirimkan dan diterima antar objek. [8]

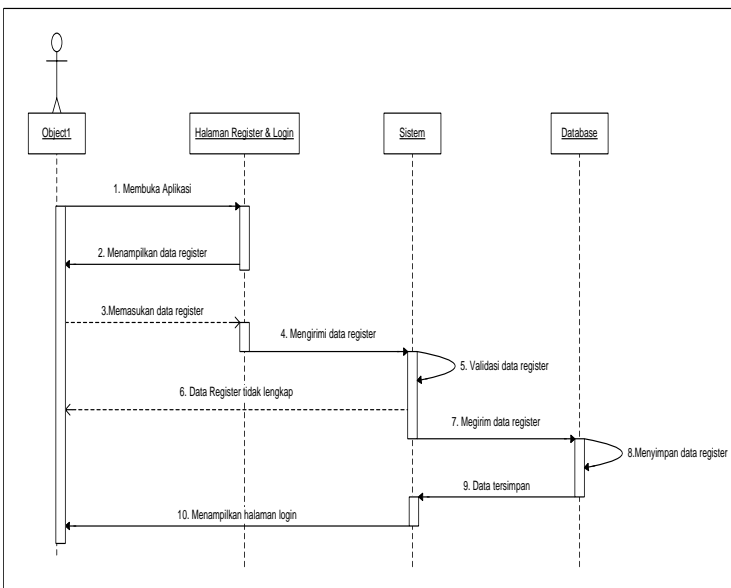

Gambar 5 Use Case E-MCard

\section{Class Diagram}

Class Diagram atau diagram kelas menggambarkan struktur aplikasi berorientasi objek dari segi pendefinisian kelas-kelas yang akan dibuat untuk membangun aplikasi. [8]

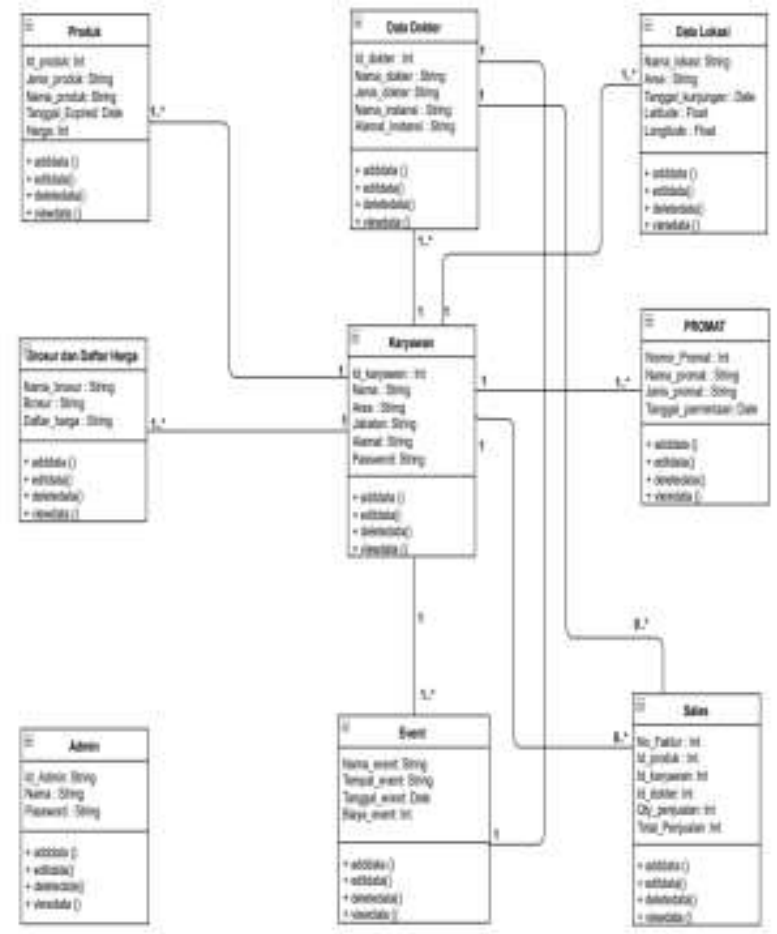

Gambar 6Class Diagram 


\section{HASIL DAN PEMBAHASAN}

Dari hasil analisis menggunakan dua metode yakni SWOT dan Fishbone bahwa masalah terbesar terdapat pada internal perusahaan itu sendiri yakni :

1. Masalah SDM ( Sumber Daya Manusia ) dimana SDM sering lupa membawa kartu kunjungan saat berkunjung ke isntansi terkait dan ini menjadai kendala bagi SDM itu sendiri dan berdampak pada gaji yang akan diterima.

2. Tidak tersedianya data pendukung untuk para Karyawan bagian pemasaran dalam melihat rekam jejak terkait data sales, pemberian support event maupun data sales.

3. Keterbatasan stok brosur produk dan kartu call yang dapat menghambat proses kerja dan pengenalan produk kepada calon user baru.

4. Kurangnya monitoring dalam menyediakan data pemberian support event workshop dan symposium kepada user.

Selain dari masalah internal tersebut, masalah eksternal juga menjadi faktor yang sangat penting yang harus diperhatikan, dimana saat ini sebagian besar perusahaan farmasi sudah menggunakan elektonik mobile dalam proses kerja karyawan bagian pemasaran, sehingga proses kerjanya lebih efisien dan dapat lebih maksimal. Oleh karena itu sangat diperlukan perancangan sistem elektronik mobile untuk membantu proses kerja karyawan bagian pemasaran pada PT. XYZ.

\section{PERANCANGAN ANTARMUKA}

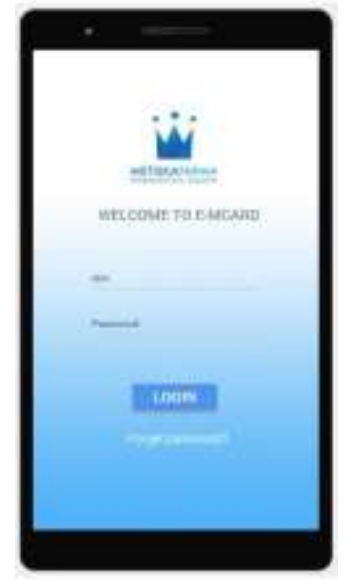

\section{Gambar 7 Tampilan Menu Registrasi}

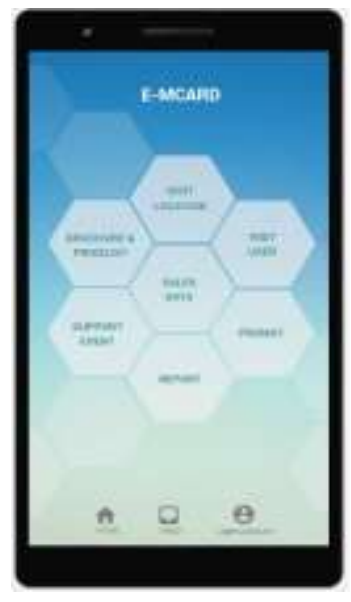

Gambar 8 Tampilan Menu

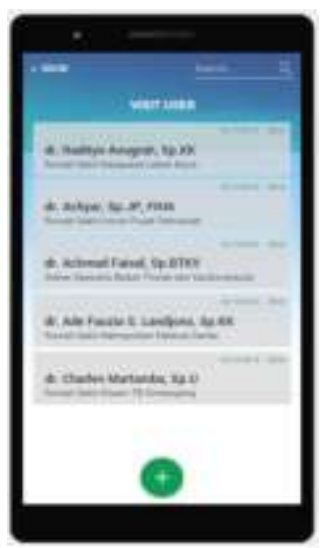

Gambar 9 Tampilan Menu Visit Dokter 


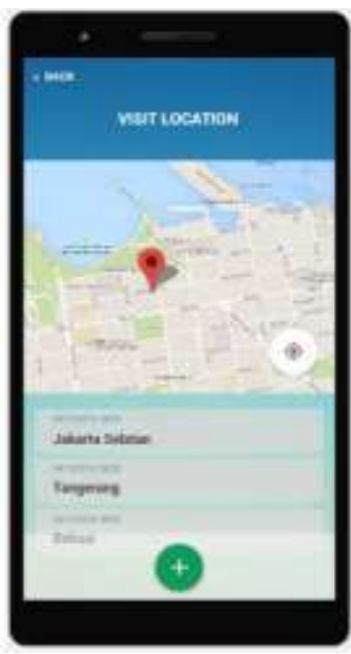

\section{Gambar 10 Tampilan Menu Kunjungan}

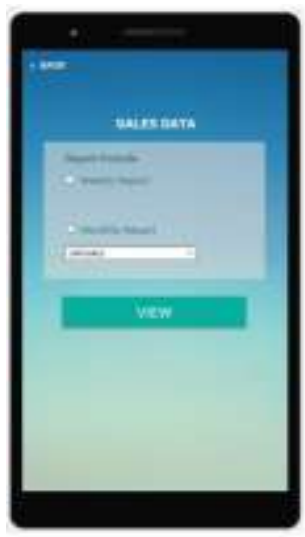

Gambar 11 Tampilan Menu Data Sales

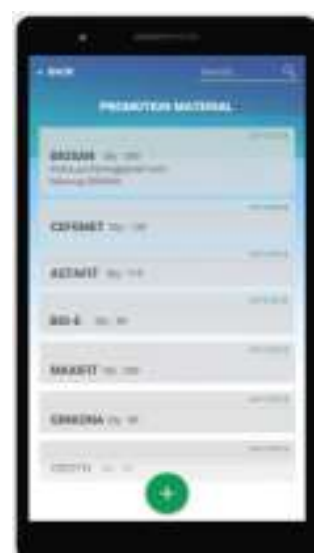

Gambar 12 Tampilan Menu Premintaan

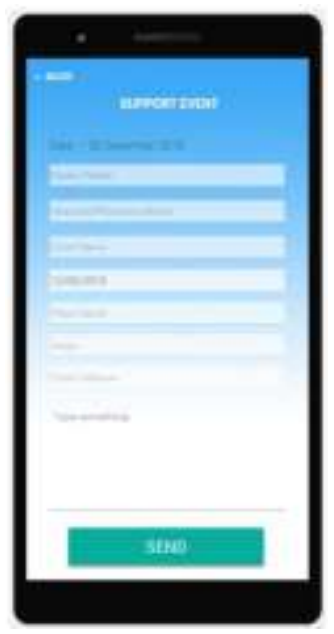

Gambar 13 Tampilan Menu Support Event

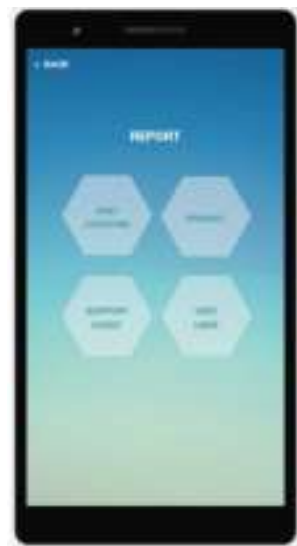

Gambar 14 Tampilan Menu View Report

\section{SIMPULAN}

Berdasarkan hasil pembahaasan analisis dan perancangan yang sudah dijelaskan sebelumnya, maka dapat ditarik beberapa kesimpulan sebagai berikut :

1. Perancangan ini memberikan solusi yang mempermudah proses pencapaian target kunjungan pada PT. $\mathrm{XYZ}$

2. Perancangan ini memberikan rancangan yang baik untuk dapat membantu pengenalan dan pemasaran produk kepada dokter.

3. Perancangan ini membuat solusi XYZ.

4. Perancangan ini dapat membantu mengetahui aktivitas pemberian support event workshop dan symposium yang diberikan kepada dokter. 
5. Perancangan ini memberikan solusi untuk membantu memonitoring pemberian PROMAT kepada dokter.

\section{DAFTAR PUSTAKA}

[1] D. Saputra, "Perancangan Enterprise Architecture Zachman Framework Untuk Jasa Layanan Pasang Baru dan Tambah Daya Listrik Pada Perusahaan JasanListrik Swasta," Jurnal Khatulistiwa Informatika, vol. III, no. 11, pp. 11-24, 2015.

[2] J. F. A. Riman Irfanto, "Perancangan Enterprise Architecture Menggunakan Zachman Framework ( Studi Kasus : PT Vivamas Adipratama )," Seminar Nasional Sains dan Teknologi 2017, no. 2, pp. 1-9, 2017.

[3] A. K. Vadreas, "Aplikasi E-Commerce dengan metode fishbone analisis pada usaha dagang hasil laut di sikakap kabupaten kepulauan mentawai menuju masyarakat ekonomi ASEAN ( MEA )," Jurnsl Momentum, vol. 18, no. 2, pp. 1118, 2016.

[4] E. H. S. Trio Indra Ruhmana, "Perancangan aplikasi untuk sirkulasi pakan ternak ayam broiler pada peternakan sumber jaya magelang," Jurnal Ilmiah DASI, vol. 14, no. 49, pp. 48-53, 2013.

[5] Irnawati, "Peran Teknologi Informasi Dalam Meningkatkan sistem pemasaran," Factor Exacta, vol. 8, no. 16, pp. 14-22, 2015.

[6] D. H. F. A. M. Ade Putri Kinanthi, "Analisis Pengendalian Persediaan Bahan Baku Menggunakan," Performa, vol. 15, no. 88, pp. 87-92, 2016.

[7] M. Rudini Putra Tanjung, "Sistem Pakar Mendeteksi Kerusakan Mesin Las Inverter Dengan Metode Certaintyfactor," INFOTEK, vol. 2, no. 63, pp. 62-64, 2017.

[8] P. Sulistyorini, "Pemodelan Visual dengan MenggunakanUMLdan Rational Rose," Jurnal Teknologi Informasi DINAMIK , vol. 15 , no. 27 , pp. 23-29, 2009.

[9] M. S. Rosa A.S, Rekayasa Perangkat Lunak, Bandung: Informatika Bandung,
2013.

[10] A. W. Yudha Yudhanto, Mudah Membuat Dan Berbisnis Aplikasi Android Dengan Android Studio, Jakarta : PT Elex Media Komputindo, 2017.

$\begin{array}{lll}92 & \text { Fakultas Teknik UMSB } & \text { ISSN 2599-2081 }\end{array}$

EISSN 2599-2090 